\title{
Effect of Feeding Systems on Bovine Milk Quality in Mexico
}

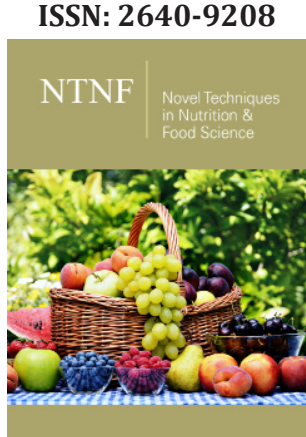

*Corresponding author: Miguel Ángel Galina Hidalgo, Facultad de Estudios Superiores Cuautitlán, Universidad Nacional Autónoma de México, México

Submission: May 7, 2021

Published: 㱔 May 21, 2021

Volume 6 - Issue 1

How to cite this article: Miguel Ángel Galina, Rosa Isabel Higuera Piedrahita, Sebastián Carrillo, Nadia Musco, Jorge Pineda, et al. Effect of Feeding Systems on Bovine Milk Quality in Mexico. Nov Tech Nutri Food Sci. 6(1). NTNF. 000627. 2021. DOI: 10.31031/NTNF.2021.06.000627

Copyright@ Miguel Ángel Galina. This article is distributed under the terms of the Creative Commons Attribution 4.0 International License, which permits unrestricted use and redistribution provided that the original author and source are credited.
Miguel Ángel Galina ${ }^{1 *}$, Rosa Isabel Higuera Piedrahita ${ }^{1}$, Sebastián Carrillo1, Nadia Musco ${ }^{2}$, Jorge Pineda ${ }^{3}$, Pedro Vázquez ${ }^{4}$, George Haenlein ${ }^{5}$, Federico Infascelli $i^{2}$ and Jorge Olmos ${ }^{6}$

${ }^{1}$ Facultad de Estudios Superiores Cuautitlán, Universidad Nacional Autónoma de México, México

${ }^{2}$ Department of Veterinary Medicine and Animal Production, University of Napoli Federico II, Italy

${ }^{3}$ Facultad de Medicina Veterinaria y Zootecnia, Universidad de Colima, México

${ }^{4}$ Centro de Investigación en Ciencia Aplicada y Tecnología Avanzada Instituto Politécnico Nacional, Querétaro, México

${ }^{5}$ Department of Animal \& Food Sciences, University of Delaware, Newark-Delaware, USA

${ }^{6}$ Facultad de Medicina Veterinaria y Zootecnia Universidad Autónoma de Querétaro, Querétaro, México

\begin{abstract}
The trial aimed to compare the fatty acid profile of milk from dairy cows under Exclusive Grazing (EG), Supplemented Grazing (SG) or Full Confinement (FC) system. Sampling was performed in 2017 and 2018 on 6707 dairy cows from Querétaro, Tabasco, Colima, Veracruz and Chiapas in Mexico. Among the 84 farms included in the trial, $25.3 \%$ were in FC (1699 animals) and fed corn silage, alfalfa hay, tropical forages and commercial balanced concentrate (16\% CP; 5 to $7 \mathrm{~kg} /$ head/day); in both extensive (EG) and supplemented (SG) grazing there was a mixture of tropical grasses: Cynodon niemfluensis, Muhlenbergia robusta, Brachiaria brizantha, B. decumbens and Echinochloa Polystachya. Group EG (30\%, 2014 heads) was permanently grazing while SG (44.6\%, 2944 heads) was also supplied with a commercial balanced feed $(18 \%$ crude protein; 2 to $3 \mathrm{~kg} / \mathrm{head} /$ day $)$. Average daily milk yield was significantly $(\mathrm{P}<0.05)$ different among groups: $16.2 \pm 2.12 \mathrm{~kg}(\mathrm{FC}), 9.5 \pm 2.72 \mathrm{~kg}(\mathrm{SG})$ and $7.2 \pm 1.530 \mathrm{~kg}(\mathrm{EG})$. The breeding system also affected milk fatty acid profile, particularly the $\omega 6 / \omega 3$ ratio: increasing the amount of concentrate in the diet significantly $(\mathrm{P}<0.05)$ increased milk $\omega 6$ or decreased $\omega 3$ concentration, thus diminishing the beneficial effects for human health.
\end{abstract}

Keywords: Milk; Grazing; PUFA; Omega fatty acids; Omega6/Omega3 ratio

\section{Introduction}

In recent years, the consumers' demand for foods with high nutritional value has strongly increased [1]. Concerning those of animal origin, it is accepted that animal diet can affect their quality [2-5]; in particular, foods produced by grazing ruminants are recognized by nearly all consumers, and farmers themselves, as high-quality foods [6]. On the other hand, dairy specialization and intensive farming have brought about an increase in the use of concentrates, thus reducing or even eliminating pasture as a feed source in many countries [7]. Indeed, in some areas like the tropics, there is still an abundant source of natural grasses and leguminous trees, that allows to feed cows in silvopasture environments, thus producing high quality milk [8]. Previous studies on the nutritional quality of milk in Mexico demonstrated several benefits of grazing in Zebu cow and goat [8]. In fact, lower content of Saturated Fatty Acids (SFA) and higher levels of $\omega 3$ Polyunsaturated Fatty Acids (PUFA), were observed in milk from grazing animals compared to that from animals in full confinement $[9,10]$. It has been proven that a lower content of SFA favors human health [6], as well as it has been demonstrated that $\omega 3$ PUFAs, in particular arachidonic acid and Docosahexaenoic Acid (DHA), are able to improve oxidative stress. This is critical, since oxidative stress is characterized by a decrease in the capacity of the endogenous system to act against oxidative attack directed to biomolecules, and it has been associated with different severe pathologies, such as cancer, cardiovascular diseases, type 2 diabetes, hypertension, and neurodegenerative diseases [6]. 
Other research focused on the importance of $\omega 6 / \omega 3$ ratio [11], suggesting a value of 4 may prevent cardiovascular diseases up to a $70 \%$ reduction in mortality. More recently, the importance of maintaining a $\omega 6 / \omega 3$ ratio lower than 4 was underlined $[12,13]$ also because, in modern diets it results higher than $10[14,15]$. Thus, milk from grazing ruminants could have beneficial effects of human health, contributing to decrease the $\omega 6 / \omega 3$ ratio of the diet. Aim of this study was to evaluate, over two years, the effect of grazing on the milk fatty acids profile, particularly the $\omega 6 / \omega 3$ ratio, by comparing 6707 lactating cows undergoing three different breeding systems in Mexico.

\section{Materials and Methods}

\section{Experimental design and treatments:}

The experiment was performed on bulk milk of 84 farms (total of 6707 dairy cows, $2^{\text {nd }}$ to $4^{\text {th }}$ parity) in Mexico, for two years: 2017 and 2018. The farms were in Querétaro (Latitude: 20.5931, Lenght: $-100.39220^{\circ}$, at $\left.1820 \mathrm{msnm}\right)$, Tabasco $\left(18^{\circ} 20^{\prime}\right.$ north latitude, $93^{\circ} 15^{\prime}$ length, 10 meters over the sea), Colima (latitude 19.2433, lenght-103.725 $19^{\circ} 14^{\prime} 36^{\prime \prime}$ North, $103^{\circ} 43^{\prime} 30^{\prime \prime}$ West, over $550 \mathrm{msnm})$, Veracruz $\left(17^{\circ} 09^{\prime}\right.$ latitude, $98^{\circ} 39^{\prime}$ length, 0 meters over the sea) and Chiapas (lenght: 093 $22^{\prime} 51.74^{\prime \prime}$ latitude: $\mathrm{N} 17^{\circ} 33^{\prime} 23.51^{\prime \prime}$, at $\left.4080 \mathrm{msnm}\right)$. In each farm, the calving's were grouped, thus, most of the cows had the same days in milk; the lactation stages considered were from 30 to 60 days postpartum and 90 to 110 days postpartum. The farms were grouped according to their feeding system: Exclusive Grazing (EG), Supplemented Grazing (SG) or Full Confinement (FC). Groups EG (30.0\%, 2014 heads) and SG (44.6\%, 2944 heads) grazed on Cynodon niemfluensis, Muhlenbergia robusta, Brachiaria brizantha, Brachiaria decumbens and Echinochloa polystachya and in one farm in Queretaro on Lolium perenne. The animals in EG were permanently grazing while those in SG were supplemented (2 to $3 \mathrm{~kg} / \mathrm{head} /$ day) with commercial balanced concentrates (18\% CP). Animals from group FC (25.3\%, 1699 heads) were fed corn silage, tropical forages (Sugarcane tops, King grass, Brachiaria sp, Star grass), alfalfa hay and commercial balanced concentrate (16\% CP; 5 to $7 \mathrm{~kg} / \mathrm{head} /$ day).

\section{Feeds and milk sampling and analysis}

In May and August of each year, bulk tank milk samples $(100 \mathrm{~mL})$ were collected once a day for three consecutive days, in a sterilized plastic falcon tube, refrigerated at $3{ }^{\circ} \mathrm{C}$ and transported to the laboratory. An aliquot of each sample was analyzed for fat, protein and lactose (MilkoScan ${ }^{\mathrm{TM}}$ 133B, Foss Matic, Hilleroed, Denmark) while another one was refrigerated at $3{ }^{\circ} \mathrm{C}$ for $4 \mathrm{~h}$, frozen at $-21{ }^{\circ} \mathrm{C}$ for $48 \mathrm{~h}$ and then lyophilized.

Contemporary, in EG and SG system pasture samples were collected as follows: grass of four different areas $\left(2.5 \mathrm{~m}^{2}\right.$ each) was cut at $3 \mathrm{~cm}$ from the ground; once weighed, 4 representative samples ( $1 \mathrm{~kg}$ each, obtained balancing the amount from the 4 different areas) were air-oven dried at $65^{\circ} \mathrm{C}$, milled through a $1 \mathrm{~mm}$ screen and analysed according to AOAC [16] for Dry Matter (DM, ID 934.01), Crude Protein (CP, ID 984.13), ether extract (EE, ID
920.29); the structural carbohydrates were also determined [17] and nutritive value (UFL=1700 kcal of net energy for lactation) was calculated [18].

\section{Milk fatty acid analyses}

Total fat of milk lyophilized samples was separated by a mixture of hexane isopropane $(3 / 2, v / v)$, according to Hara and Radin [19]. Transmethylation of fatty acids was performed by the basecatalysed procedure described by Christie [20] and modified by Chouinard et al. [21]. FAME were quantified by Gas Chromatography (GC) using a CP-3380 chromatograph equipped with a split injector, Flame Ionization Detector (FID) and auto sampler CP 8400. A DB23 column ( $30 \mathrm{~m} \times 0.25 \mathrm{~mm}$ i.d.) with a film thickness of $0.25 \mu \mathrm{m}$ was employed. Nitrogen was used as carrier gas at a flow rate of $30 \mathrm{ml} /$ min. TTemperature'scolumn was held for $1 \mathrm{~min}$ at $120^{\circ} \mathrm{C}$, then programmed at rate of $10{ }^{\circ} \mathrm{C} / \mathrm{min}$ to $200{ }^{\circ} \mathrm{C}$ and held for $5{ }^{\circ} \mathrm{C} / \mathrm{min}$ to final temperature of $230{ }^{\circ} \mathrm{C}$; temperature injector and FID were $250{ }^{\circ} \mathrm{C}$ and $300^{\circ} \mathrm{C}$, respectively. Integration for each fatty acid was performed by a Varian Star Chromatography Workstation Software. Identification of the peaks was made on the basic of the retention times of standard methyl esters of individual fatty acid (FAME mix C4-C24 \#18919-1 AMP). The final concentration of FAME was expressed as $\mathrm{mg} / 100 \mathrm{~g}$ of milk.

\section{Atherogenic and thrombogenic index}

To better characterize the milk nutritional characteristics, the Atherogenic Index (AI) and the Thrombogenic Index (TI) were calculated according to Ulbricht and Southgate (1991):

$$
\begin{gathered}
\mathrm{AI}=[\mathrm{C} 12: 0+(4 \times \mathrm{C} 14: 0)+\mathrm{C} 16: 0] /(\omega-3+\omega-6+\mathrm{MUFA}) \\
\mathrm{TI}=(\mathrm{C} 14: 0+\mathrm{C} 16: 0+\mathrm{C} 18: 0) /[(0.5 \times \mathrm{C} 18: 1)+(0.5 \times \text { other } \\
\text { MUFA })+(0.5 \times \omega-6)+(3 \times \omega-3)+(\omega-3 / \omega-6)] .
\end{gathered}
$$

where:

C12: 0 = lauric acid, C14: $0=$ myristic acid, C16: 0= palmitic acid, C18: 0 = stearic acid, C18: 1 = oleic acid,

In the equations, $\mathrm{C} 14: 0$ is considered to be 4 times more atherogenic than other FAs. To the C18:1, the omega 6 PUFA and to the rest of MUFA coefficients of 0.5 have been assigned because they are less anti-atherogenic than the omega 3 , to which a coefficient of 3 was assigned.

\section{Statistical analysis}

All the data were analyzed using a one-way ANOVA design. Data analysis was carried out using the General Linear Model Procedures (Statgraphics- Centurion), calculated with Statistical Analysis System [22].

\section{Result}

\section{Feed analysis}

The chemical composition of the diets fed by animals in the different breeding systems is reported in Table 1 . The highest content of crude protein and the lowest NDF and ADF percentages were registered in FC while EG showed opposite results. Consequently, the diet nutritive value increased with the increase 
of concentrate in the diet (UFL/kg DM: $0.75-0.76$ vs $0.78-0.80$ vs 0.83-0.87, for EG, SG and FC system, respectively).

Table 1: Diet chemical composition (\%DM) and nutritive value (MUF/kg DM) in Exclusive Grazing (EG), Supplemented Grazing (SG) and confinement (FC) system.

\begin{tabular}{|c|c|c|c|}
\hline & EG & SG & FC \\
\hline CP & $13.4-14.6$ & $13.8-15.0$ & $14.1-15.6$ \\
\hline NDF & $40.4-44.0$ & $36.1-39.0$ & $31.1-33.3$ \\
\hline ADF & $28.4-30.2$ & $27.1-29.3$ & $22.5-24.1$ \\
\hline $\mathrm{UFL} / \mathrm{kg}$ DM & $0.75-0.76$ & $0.78-0.80$ & $0.83-0.87$ \\
\hline
\end{tabular}

CP: Crude Protein; NDF: Neutral Detergent Fiber; ADF: Acid Detergent Fiber; UFL: net energy for lactation.

\section{Milk yield}

Average milk yield was $\mathrm{kg} 7.2 \pm 1.53$ vs $9.54 \pm 2.72$ vs $16.20 \pm 2.12 \mathrm{~kg}$, for EG, SG and FC respectively Milk chemical composition was unaffected by treatment (Table 2).

Table 2: Milk chemical composition (g/kg).

\begin{tabular}{|c|c|c|c|}
\hline & EG & SG & FC \\
\hline Fat & $45.0 \pm 1.1$ & $44.7 \pm 2.0$ & $44.0 \pm 2.2$ \\
\hline Protein & $35.1 \pm 1.0$ & $35.1 \pm 2.1$ & $35.0 \pm 1.1$ \\
\hline Lactose & $49.1 \pm 1.1$ & $48.4 \pm 2.0$ & $49.0 \pm 1.0$ \\
\hline
\end{tabular}

EG: Exclusive Grazing; SG: Supplemented Grazing; FC: Full Confinement.

\section{Milk fatty acid profile}

Myristic (C14:0), margaric (C17:0) and stearic (C18:0) acids, as well as total SFA, were significantly $(\mathrm{P}<0.05)$ higher in milk from $\mathrm{FC}$ than SG and EG. Group EG showed the lowest value of palmitic acid $(\mathrm{C} 16: 0)(28.12 \mathrm{~g} / 100 \mathrm{~g})$ statistically different $(\mathrm{P}<0.05)$ from both SG $(30.00 \mathrm{~g} / 100 \mathrm{~g})$ and FC $(32.13 \mathrm{~g} / 100 \mathrm{~g})$. The other SFAs were not significantly different among the breeding systems (Table 3).

Table 3: Milk chemical composition (g/kg).

\begin{tabular}{|c|c|c|c|}
\hline & EG & SG & FC \\
\hline C4:0 & $0.60 \pm 0.15$ & $0.62 \pm 0.16$ & $0.50 \pm 0.17$ \\
\hline C6:0 & $0.85 \pm 0.21$ & $0.81 \pm 0.19$ & $0.70 \pm 0.13$ \\
\hline C8:0 & $0.78 \pm 0.17 \mathrm{~b}$ & $0.67 \pm 0.14 \mathrm{a}$ & $0.70 \pm 0.12 \mathrm{ab}$ \\
\hline C10:0 & $1.92 \pm 0.84$ & $1.71 \pm 0.32$ & $1.92 \pm 0.23$ \\
\hline C12:0 & $2.44 \pm 0.48$ & $2.28 \pm 0.44$ & $2.55 \pm 0.46$ \\
\hline C14:0 & $9.62 \pm 1.06 \mathrm{a}$ & $9.58 \pm 1.42 \mathrm{a}$ & $11.91 \pm 1.23 \mathrm{~b}$ \\
\hline C15:0 & $1.74 \pm 0.26$ & $1.70 \pm 0.28$ & $1.67 \pm 0.47$ \\
\hline C16:0 & $28.12 \pm 2.41 \mathrm{a}$ & $30.00 \pm 2.84 \mathrm{~b}$ & $32.13 \pm 2.95 \mathrm{~b}$ \\
\hline C17:0 & $1.44 \pm 0.21 \mathrm{~b}$ & $1.44 \pm 0.23 \mathrm{~b}$ & $1.12 \pm 0.24 \mathrm{a}$ \\
\hline C18:0 & $15.76 \pm 1.75 \mathrm{ab}$ & $14.70 \pm 3.87 \mathrm{a}$ & $17.46 \pm 0.82 \mathrm{~b}$ \\
\hline C20:0 & $0.43 \pm 0.12 \mathrm{~b}$ & $0.44 \pm 0.12 \mathrm{a}$ & $0.51 \pm 0.10 \mathrm{ab}$ \\
\hline SFA & $63.71 \pm 4.23 \mathrm{a}$ & $63.96 \pm 2.67 \mathrm{a}$ & $71.17 \pm 3.50 \mathrm{~b}$ \\
\hline
\end{tabular}

EG: Exclusive Grazing; SG: Supplemented Grazing; FC: Full Confinement; Means with different letters indicate differences $(\mathrm{P}<0.05)$ among breeding systems
Milk from SG showed the highest concentration, even if not significantly different, of unsaturated fatty acids (UFA): $35.76 \mathrm{~g} / 100 \mathrm{~g}$ vs $35.09 \mathrm{~g} / 100 \mathrm{~g}$ vs $34.62 \mathrm{~g} / 100 \mathrm{~g}$, for SG, EG and FC, respectively. Concerning the monounsaturated fatty acids (MUFA), milk from EG had the highest concentration (32.35g/100g) compared to FC $(31.42 \mathrm{~g} / 100 \mathrm{~g})$ and SG $(32.27 \mathrm{~g} / 100 \mathrm{~g})$, but, again, the differences were not significant. Similar results were found for the Polyunsaturated Fatty Acids (PUFA) concentration with no statistical difference among the breeding systems. The most representative acid in milk from all the systems was the oleic acid (C18:1) followed by linoleic acid (C18:2) and palmitoleic acid (C16:1) (Table 4). The $\omega 6 / \omega 3$ ratio was significantly $(\mathrm{P}<0.05)$ different among the systems: group $\mathrm{FC}$ had the highest value (6.21:1) followed by SG (3.35:1) and EG (2.07:1). This result was mainly due to the different linolenic acid (C18:3) concentration among the groups. Concerning $\omega 6$ FA, a significant lower concentration $(\mathrm{P}<0.05)$ was found for linoleic acid $(\mathrm{C} 18: 2)$ in milk from EG compared to those from the other systems (Table 4). Both the Atherogenic (AI) and Thrombogenic (TI) indexes were higher for FC than EG and SG, but a statistical difference $(\mathrm{P}<0.05)$ was seen only for TI (Table 5).

Table 4: Milk unsaturated fatty acids (UFA) profile (g/100g).

\begin{tabular}{|c|c|c|c|}
\hline & EG & SG & FC \\
\hline C14:1 & $1.10 \pm 0.46 \mathrm{a}$ & $1.40 \pm 0.40 \mathrm{~b}$ & $1.33 \pm 0.25 \mathrm{ab}$ \\
\hline C16:1 & $1.52 \pm 0.49 \mathrm{a}$ & $2.13 \pm 0.68 \mathrm{~b}$ & $1.85 \pm 0.26 \mathrm{ab}$ \\
\hline C18:1 & $29.73 \pm 3.66$ & $28.74 \pm 2.31$ & $28.24 \pm 2.64$ \\
\hline C18:2 & $1.84 \pm 0.75 \mathrm{a}$ & $2.67 \pm 1.35 \mathrm{~b}$ & $2.75 \pm 0.47 \mathrm{~b}$ \\
\hline C18:3 & $0.90 \pm 0.27 \mathrm{~b}$ & $0.82 \pm 0.40 \mathrm{~b}$ & $0.45 \pm 0.10 \mathrm{a}$ \\
\hline MUFA & $32.35 \pm 3.88$ & $32.27 \pm 2.22$ & $31.43 \pm 2.31$ \\
\hline PUFA & $2.74 \pm 0.96$ & $3.49 \pm 1.72$ & $3.20 \pm 0.53$ \\
\hline UFA & $35.09 \pm 4.37$ & $35.76 \pm 3.18$ & $34.63 \pm 2.50$ \\
\hline$\omega 6 / \omega 3$ & $2.07 \pm 0.52 \mathrm{a}$ & $3.35 \pm 0.67 \mathrm{~b}$ & $6.21 \pm 1.24 \mathrm{c}$ \\
\hline
\end{tabular}

EG: Exclusive Grazing; SG: Supplemented Grazing; FC: Full Confinement; MUFA: Monounsaturated Fatty Acids; PUFA: Polyunsaturated Fatty Acids; UFA: Unsaturated Fatty Acids; $\omega 6 / \omega 3$ : Omega6/Omega3 ratio. Means with different letters indicate differences $(\mathrm{p}<0.05)$ among breeding systems.

Table 5: Milk atherogenic (AI) and thrombogenic (TI) index.

\begin{tabular}{|c|c|c|c|}
\hline & EG & SG & FC \\
\hline AI & $2.02 \pm 0.48$ & $1.99 \pm 0.31$ & $2.39 \pm 0.25$ \\
\hline TI & $1.56 \pm 0.32 \mathrm{a}$ & $1.58 \pm 0.19 \mathrm{a}$ & $1.89 \pm 0.22 \mathrm{~b}$ \\
\hline
\end{tabular}

EG: Exclusive Grazing; SG: Supplemented Grazing; FC: Full Confinement. Means with different letters indicate differences $(\mathrm{p}<0.05)$ among breeding systems.

\section{Discussion}

The breeding system significantly affected milk yield which increased with the increase of concentrate in the animals' diet. Concerning milk chemical composition, fat percentage was higher 
when animals had access to pasture but the differences with the full confinement system were not significant. By contrast, milk fatty acid profile was significantly healthier in the grazing than in the full confinement systems. Indeed, Park et al. [22], Jensen [23], Chapkin [24], and Banskalieva et al. [25] discussed that fat and cholesterol have worldwide increased in human's diet, thus becoming a serious health risk due to coronary and vascular problems. According to these authors, the consumption of saturated fatty acids, particularly lauric (C12:0) myristic (C14:0) and palmitic (16:0), are related to hypercholesterolemia due to an increase in plasma Low Density Lipoproteins (LDL) while stearic (C18:0) and oleic acid (C18:1) decrease LDL and increase High Density Lipoproteins (HDL), favoring liver formation of Very Low-Density Lipoproteins (VLDL) that allows cholesterol to be transformed to gall bladder salts. Data in the present trial confirmed this low potential hypercholesterolemic effect of milk from grazing animals; in fact, milk from exclusive grazing had significantly lower contents of both myristic (C14:0) and palmitic (16:0) acids, and milk from supplemented grazing only of palmitic acid than that from full confinement system.

Despite a similar content of oleic acid (C18:1), milk from EG and SG showed 50\% higher content of linolenic acid (C18:3) than that from FC group. Some studies reported modifications of milk fatty acid profile as a function of animals' diet: in particular, a decrease of C16:0 and an increase of C18:0 and C18:1 content was observed in cows grazing pasture compared to cows fed a total mixed ration [26,27]. Concerning $\omega 6$ and $\omega 3$ PUFA, it has been shown that milk contents of both linoleic acid (C18:2, $\omega 6)$ and linolenic acid $(\mathrm{C} 18: 3, \omega 3)$ are affected by the feeding system [28]. Similarly, in the present study, the highest content of linoleic acid was in milk from FC while that of linolenic acid in milk from EG. Decreasing milk $\omega 6 / \omega 3$ ratio showed several beneficial effects for human health $[5,15]$, particularly with values lower than 4 , since higher levels could modify the beneficial effects of $\omega 3[14,15]$. In present trial, the relationship between breeding system and milk $\omega 6 / \omega 3$ ratio was shown feeding animals with higher quantity of concentrates increased milk yield and $\omega 6 / \omega 3$ ratio. Similar results were reported by Salado et al. [29], in a study aimed to evaluate the effects of diets with different levels of concentrate (3.5, 7.0 and $10.5 \mathrm{~kg} /$ day) on milk yield and quality of grazing dairy cows in early lactation.

These authors registered higher milk yield and protein in groups fed 7.0 and $10.5 \mathrm{~kg} /$ day than in group fed $3.5 \mathrm{~kg}$ of concentrate. In contrast, milk fat did not differ among the groups and, even if the potential hypercholesterolemic fatty acids of milk (C12:0 to C16:0) did not change by increasing concentrate intake, linolenic acid decreased and the $\omega 6 / \omega 3$ ratio increased in groups fed higher amounts of concentrate. Corazzin et al. [30] evaluated the effect of concentrate supplementation (High: $3.0 \mathrm{~kg} / \mathrm{head} / \mathrm{d}$ vs. Low: $1.5 \mathrm{~kg} /$ head/d) on milk fatty acid profile of Italian Simmental dairy cows grazing on alpine pasture. Low milk showed higher concentration of linolenic acid and total PUFA than High milk. Recently, Santa-Ana et al. [31] and Galina et al. [32] compared two breeding systems for goats, full confinement or grazing: milk from animals fed on pasture showed higher PUFAs and MUFAs and lower SFAs with a significant reduction of atherogenic index, thus presumably more beneficial for human health.

Musco et al. [33] evaluated the effects of a feeding strategy (based on the use of outdoor paddocks; forage: concentrate ratio at least 70:30; forage including at least five different herbs; and no silages) in dairy cows on milk yield and chemical composition, and blood metabolic profile, including the evaluation of oxidative stress. These authors reported that the proposed feeding system was able to increase milk quality, mainly in terms of fats quality, without negative effects of animal health. Animals fed higher forage: concentrate diet were able to maintain body homeostasis by changing metabolism despite the low energy diet and they showed a general improvement of oxidative status, probably due to an improvement of the biological antioxidant potential. All these results showed that, even considering the differences among ruminants, management on grazing is the key component to improve omega relationship.

Finally, both milk Atherogenic (IA) and Thrombogenic Index (IT) were affected by breeding system. They take into account the potential effect of each fatty acid on human health, and they were lower for grazing than full confinement animals. Thus, milk from grazing animals should have low probability of increasing the incidence of atheroma and/or thrombus formation [34]. The possibility of producing healthier milk by grazing may be of great importance in those areas, like Mexico, still plenty of natural grasses. Also, further studies in the same areas should confirm the hypothesis that grazing may be also beneficial for animals' health, thus addressing the increasing concerns about animal welfare [35].

\section{Conclusion}

The breeding system resulted as a fundamental aspect to determine the nutritional quality of milk, mainly related to its fatty acid profile. Despite an increase of milk yield, the full confinement system showed a worsening of healthier parameters: $\omega 6 / \omega 3$ ratio greater than 4:1 and increase of both atherogenic and thrombogenic indexes. Therefore, in response to the consumer demand for foods with high nutritional quality, the grazing systems has to be encouraged and milk from animals with free access to pasture has to be recommended.

\section{References}

1. Slots T, Butler G, Leifert C, Kristensen T, Skibsted LH, et al. (2009) Potential to differentiate milk composition by different feeding strategies. J Dairy Sci 92(5): 2057-2066.

2. Tudisco R, Calabrò S, Cutrignelli MI, Moniello G, Grossi M, et al. (2012) Influence of organic systems on Stearoyl-CoA desaturase gene expression in goat milk. Small Rum Res 106: S37-S42.

3. Tudisco R, Grossi M, Calabrò S, Cutrignelli MI, Musco N, et al. (2014) Influence of pasture on goat milk fatty acids and Stearoyl-CoA desaturase expression in milk somatic cells. Small Rum Res 122(1-3): 38-43.

4. Cabiddu A, Molie G, Decandin M (2017) Influence of the goat breeding system on the vitaminic and phenolic composition of milk. Dairy Science and Technique 68(3-6): 67-68. 
5. Galina MA, Pineda J, Piedrahita RH, Vázquez P, Haenlein G, et al. (2019) Effect of grazying on the fatty acid composition of goat's milk or cheese. Adv Dairy Res 7(3): 227.

6. Pisoschi AM, Pop A (2015) The role of antioxidants in the chemistry of oxidative stress: A review. Europ J Med Chem 97: 55-74.

7. Castel JM, Mena Y, Ruiz FA, Ruiz JC, Rodriguez MS (2011) Changes occurring in dairy goat production systems in less favored areas of Spain. Small Rumin Res 96(2-3): 83-92.

8. Galina MA, Osnaya F, Cuchillo HM, Haenlein GFW (2007) Cheese quality from milk of grazing or indoor fed Zebu cows and Alpine crossbred goats. Small Rumin Res 71: 264-272.

9. Claps S, Galina MA, Rubino R, Pizzillo M, Morone G, et al. (2014) Effect of grazing into the omega 3 and aromatic profile of bovine cheese. J Nutr Ecology and Food Res 2(3): 245-250.

10. Galina MA, Elías A, Vázquez P, Pineda J, López B (2016) Effect of fermentation promoters, with or without probiotics, on the profile of fatty acid, amino acid and colesterol profile in grazing cows. Cuban J Agric Sci 50(1): 1-16.

11. Simopoulos AP (2002) The importance of the ratio of omega6/omega3 essential fatty acids. Biomed Pharmaco 56(8): 365-379.

12. Cavaliere G, Trinchese G, Musco N, Infascelli F, Filippo C, et al. (2018) Milk from cows fed a diet with a high forage: concentrate ratio improves inflammatory state, oxidative stress, and mitochondrial function in rats. J Dairy Sci 101(3): 1843-1851.

13. Trinchese G, Cavaliere G, Penna E, Filippo C, Cimmino F, et al. (2019) Milk from cow fed with high forage/concentrate ratio diet: beneficial effect on rat skeletal muscle inflammatory state and oxidative stress through modulation of mitochondrial functions and AMPK activity. Frontiers in Phys 9: 1969.

14. Colavilla G, Amadoro C, Mignona R (2014) Ratio omega6/omega3 and GPA in the Noble Milk in Molise en R Rubino. The Noble Milk Model another way is possible. Edit Anfosc Caseus Italy, pp. 118-128.

15. Candela CG, López LB, Kohem VL (2011) Importance of a balanced omega6/omega3 ratio for the maintenance of health. Nutritional recommendations. Nutr Hosp 26(2): 323-329.

16. AOAC (2012) Official methods of analysis. (19 th $e d n)$, Association of Official Analytical Chemists. Arlington, VA, USA.

17. Soest PJ, Robertson JB, Lewis BA (1991) Methods for dietary fiber, neutral detergent fiber, and no starch polysaccharides in relation to animal nutrition. J Dairy Sci 74(10): 3583-3598.

18. INRA (1978) Alimentation des ruminants. INRA: Paris, France.

19. Hara A, Radin NS (1978) Lipid extraction of tissues with a low-toxicity solvent. Anal Biochem 90(1): 420-426.

20. Christie WW (1992) A simple procedure of rapid transmethylation of glycerolipids and cholesteryl esters. J Lipid Res 23(7): 1072-1075.
21. Chouinard PY, Corneau L, Barbano DM, Metzger LE, Bauman DE (1999) Conjugated linoleic acids alter milk fatty acid composition and inhibit milk fat secretion in dairy cows. J Nutr 129(8): 1579-1584.

22. Park WY, Juárez M, Ramos M, Haenlein GFW (2016) Physico chemical characteristics of goat and sheep milk. Small Rumin Res 68: 88-113.

23. Jensen RG (2000) Fatty acids in milk and dairy products. In: Chow C (Ed.), Fatty acid in foods and their health implications. Marcel Dekker, USA, pp.109-124.

24. Chapkin RS (2000) Reappraisal of the essential fatty acids. Chow C (Ed.), Fatty acid in foods and their health implications. Marcel Dekker, USA pp. 557-568.

25. Banskalieva V, Sahlu T, Goetsch AL (2003) Fatty acid composition of goat muscles and fat deposits: A review. Small Rumin Res 37(3): 255-268.

26. Kelly ML, Kolver ES, Bauman DE, Amburgh ME, Muller LD (1998) Effect of intake of pasture on concentrations of conjugated linoleic acid in milk of lactating cows. J Dairy Sci 81(6): 1630-1636.

27. Delaby L, Peyraud J, Delagarde R (2001) Effect of the level of concentrate supplementation, herbage allowance and milk yield at turn-out on the performance of dairy cows in mid lactation at grazing. Animal Sci 73(1): 171-181.

28. Zlatanos S, Laskaridis K, Feist C, Sagredos A (2002) CLA content and fatty acid composition of Greek Feta and hard cheeses. Food Chem 78(4): 471-477.

29. Salado EE, Bretschneider G, Cuatrin A, Descalzo AM, Gagliostro GA (2017) Milk yield and composition and pasture ruminal digestion in grazing dairy cows receiving three levels of energy concentrate supplementation. Agricultural Sci 8(10): 1135-1156.

30. Corazzin M, Romanzin A, Sepulcri A, Pinosa M, Piasentier E, et al. (2019) Fatty acid profiles of cow's milk and cheese as affected by mountain pasture type and concentrate supplementation. Animals 9(2): 68.

31. Santa-Ana A, Bessa R, Alves S, Medeiros A, Costa R, et al. (2019) Fatty acid, volatile and sensory profiles of milk and cheese from goats raised on native samiarid pasture or in confinement. Internat Dairy J 91: 147154.

32. Galina MA, Ortíz-Rubio MA, Guerrero CM, Vazquez P, Pineda LJ (2016) Effect of feeding management on the nutritional composition of artisan soft cheese made with ewe's milk. J Nutr Ecology Food Res 3(1): 25-31.

33. Musco N, Tudisco R, Grossi M, Mastellone V, Morittu VM, et al. (2020) Effect of a high forage: concentrate ratio on milk yield, blood parameters and oxidative status in lactating cows. Anim Prod Sci 60(12): 1531-1538.

34. Ulbricht T, Southgate D (1991) Coronary heart disease: seven dietary factors. Lancet 338(8773): 985-992.

35. SAS Institute Inc. (1996) Statistical analysis system. User's Guide Statistics. (12 ${ }^{\text {th }}$ edn), Carly, North Carolina, USA, pp. 320 